\title{
CONCEPTION OF LINGUISTIC AND METHODOLOGICAL COMPETENCES FORMATION OF TEACHERS: THEORETICAL AND TECHNOLOGICAL ASPECTS
}

\section{Bozhok O. S.}

\section{INTRODUCTION}

The problem of the demand in foreign communication becomes extremely special in the conditions of the process of settling the Ukrainian great power statehood. This issue stimulates the necessity of the evaluation of the society's potential in culture, in education and in preparation of the specialists in particular.

The lack of generally recognized concept of the students' linguistic and methodological competences as the competence of the future school teachers determines Ukraine to affiliate to the European secondary and high education systems. In accordance with the logic of our research the terms "formation" and "the concept of model's formation" are needed the support and concrete definitions. There are different nice shades of meanings of these terms in the philosophical, historical and pedagogical contexts. We will start with discovering their content. In the philosophical dictionaries the term "formation" is interpreted as a process that gives a shape, completeness; this term means the process of the physical development; the particular view of the process of growth; something that is being created ${ }^{1}$. The representatives of psychological school make an accent on the development of the potential of personality, its reserved abilities, its cognitive and creative activities due to the process of mastering of students' scientific, professional and social knowledge and skills ${ }^{2}$.

The pedagogues identify the term "formation" with the professional formation of the future specialists, the formation of their professional skills, abilities, self-development and professional competence ${ }^{3}$. S. Sysojeva studies the pedagogical management of personality as the systematic

\footnotetext{
${ }^{1}$ Алексеева И.С. Профессиональное обучение переводчика : учебнное пособие по устному и письменному переводу для переводчиков и преподавателей. СанктПетербург : Союз, 2001. 288 с.

2 Якиманська И.С.Личностно ориентированное обучение в современной школе. Москва : Издат. фирма «Сентябрь» 1996.92 с.

3 Педагогічні технології в неперервній освіті : монографія / С.О. Сисоєва, А.М. Алексюк, П.М. Воловик та ін. ; за ред. С.О. Сисоєвої. Київ : Віпол, 2001. 502 с.
} 
reasonable and indirect process of the organization and control. Consequently, the model of the linguistic and methodological competences is guided on the process of the Ego-personality of the future school teacher with the target to obtaining the mature professional activity. This leads to the formation of key and subject competences of the future school teacher.

The aim of the education is to form the competences and significant qualities of student as an individual. Accordingly, the key competences are projected based on the sectoral competences, which are divided into subject competences. At the same time, the key competences are the voluntary set of sectoral and subject competences: they integrate the sectoral competences into the complex structure where the elements are connected to each other through the different links and relations.

The purpose of the article is to: provide content analysis of the conception of linguistic and methodological competences formation of the future school teachers in the primary school; define the influence of the online didactic games on the process of future English language teachers' training; present the basic components of the online didactical games complex.

\section{Approaches and principles of linguistic and methodological competences}

The theoretical and technological guidelines of the organization and management of the formation of language and methodological competences are determined such approaches: competence approach, communicative approach, the approach of activity, the approach of personality's orientation, technological, systematical and integrative approaches as well.

The technological approach provides the search of means to achieve the goals of learning which are caused by the increase of education in the conditions of applying standards of professional training. As the didactics is the part of pedagogy then it agues and studies the purpose, the content and methods of learning process and it projects the further stages. Among its targets, there are the formation of the professional competence as the purpose, means and methods to achieve the effective results of learning under the terms of integral functioning of individual, instrumental and methodological factors.

The characteristic of technological approach is its realization within the use of based pedagogical complex of learning technologies, which have the accurate processing structure, the determined conditions and the stages of its application. Moreover, the predicted results are evaluated clearly and quantitatively.

The changes in the content and methodology of the students' education that are caused by the introduction of technological approach give the future 
school teachers the opportunity to study on the basis of innovation technologies with the mobility to use them in the modern school taking into account the specific character of school education process, to use actively the new methods of learning (as for instance, the online didactical game which appears to be an interactive mean of the dialogue interaction and context learning. The systematical approach is based on the principles of integrity (the defining of the object through the connection of the links and components), organization (the structure regularity of object) and the complexity (the division of the whole into parts, another words the hierarchy of the object construction). It also provides the emphasizing the competence as the system with the proper structure, the linked components and the complex of teacher training process ${ }^{4}$.

The providing of the integrative approach to the educational process will have to influence positively to the development of students' skills to perceive and comprehend language and methodological knowledge as the whole. Due to this capacity, the future teacher will be able to teach children at school the foreign language in accordance with the modern requirements.

The studying and summarizing the experience of the formation of foreign and methodological competences in the frames of didactical approaches are contributed to the defining of the main principles of the formation of language and methodological competences of the future foreign language teachers at school. We are going to define and to characterize them. Under the definition "principles" of formation of linguistic and methodological competences we understand the whole complex of requirements and statements for their providing. The researchers define the general and special principles.

The common characteristic, which unites the principle of the systematic character and the use of visual methods principle, is providing the logical sequence of operations. In our research, the use of visual methods principle requires the demand to the linguistic and didactical competences, namely the linguistic and phonetic competences.

The content of the verbal use of visual methods forms as the skills in pronunciation of lexical units that are necessary to form the lexical competence (that is the mastering the new lexical units), as the skills of phonetic competence (the skills of recognizing and identifying the sound units of the language). In mentioned conditions, the verbal use of visual methods helps future school teachers to develop the skills to recognize and

${ }^{4}$ Сідун М.М. Формування професійної компетентності майбутнього вчителя іноземної мови початкової школи засобами навчальних ситуацій : дис. ... канд. пед. наук :13.00.04 «Теорія і методика професійної освіти»/ Інститут педагогіки НАПН України. Київ, 2013. 248 с. 
memorize the lexical units and to identify the phonetic ones in the process of game-playing technologies of learning. Non-verbal use of visual methods can be used with the help of the drawings, scheme, diagram etc.

The scientists consider the aim of use of visual methods is in the demonstration of the objects or elements of operations, which can be perceived by eyesight and therefore the opportunity to illustrate the important signs of definitions.

The objects of non-verbal use of visual methods are the schemes, diagrams, the language constructions that give the visual form of the additional information, set proper cognitive tasks, provide the graphically schematic bases for interactive training of vocabulary ${ }^{5}$. Therefore, we can define the next following principles paying attention on using the online didactical games:

- The dynamic of self-education principle points out the attraction of students to the organization and participation in online didactical games and the accomplishment the pedagogical tasks,. This principle is realized due to the active educational activity, the optimizing of the process of the linguistic and methodological competences formation of students (the future school teachers) and individual psychological characteristics of the future teachers, their skills to overcome the difficulties, to think critically and to improve themselves, to be in the endless research activity of the innovative methods of foreign language teaching;

- The principle of teaching communicative inter-operation is being implemented through the use of integrated complex technologies. Thanks to the interaction the students are attracted to the reflexive dialogue with the participants of the learning process and they create the learning and reflexive environment. During this process the didactical game plays the role of the formation of positive dialogue interaction of the participants of learning process and it indicates the intercommunication of the linguistic and methodological competences and influences on the process of teaching at school;

- The principle of the appraisement of effectiveness - it means the awareness by the future specialists the sense of education, the meaning of the learning process, the self-analysis of their psychological virtue, their professional and individual development and the comprehension of the development of other participants of pedagogical process.

5 Саюк В.І. Професійна підготовка вчителя до ігрових технологій навчання. Післядипломна освіта: перспективи розвитку : матеріали звітн. наук.-практ. конф., 28 листопада 2000 р. / Центр. ін-т післядипломної пед. освіти АПН України ; редкол. : В.Олійник та ін. Київ, 2001. Ч. 2. С. 123-128. 
The mentioned approaches and principles are included to the functional conception of the linguistic and methodological competences formation of the future school teachers and they are considered as a part of the complete positive influence of the qualitative competences formation. The selection and characteristics of these approaches and principles are not enough for completing the process. They open, add and increase the so-called boundaries of building and creating the conception to form the students' competences.

Thus, the characterized approached and principles draw the base of linguistic and methodological competences formation of the future foreign language school teachers. On this base, the combined methodological approaches are created and they are also included to our investigated structural and functional model of the competences formation of the future foreign language school teachers.

The conception of "model" is represented in the pedagogical literature as the opportunity to figure in the science the existence and application of any object for its further investigation and analysis; this term is also represented as the theoretical guide for further construction of the definite object; and it is considered as the visualization of the object's imaging.

The Ukrainian researcher S. Goncharenko (1997) compared the "model" with the manual that containes the visual imaging of some objects (for example, it can be a scheme, a picture, a description etc.). The scientist considered that this would safe the proportions and resemblance of the parts of the mentioned objects on conditions of the systematization and conventionality of objects' representation ${ }^{6}$.

In our research work we take into account the philosophers' opinion of the definition of the notion "model". So they consider it to be something that is created in the mind or the prototype that is fulfilled in the reality. In their opinion this identification is able to change the object of investigation, therefore it gives a chance to perceive the information about the model of the researched object.

Consequently, we are able to make a conclusion that the model is the system that realy exists, functions and changes the quality of investigation of the object. We understand that such kind of model integrates the combination of elements and eliminates the connection between them.

We accept the conception of I. Yakimanska (2009) who considered that the presence of integrated function is in the following: on conditions of the researchment of the problems and the received results in the other fields it can influence on the sphere of the pedagogical investigations using the same phases in the same consistency. Accordingly, the creation and the

\footnotetext{
${ }^{6}$ Гончаренко С. Український педагогічний словник. Київ : Либідь, 1997. 376 с.
} 
development of the system foresee the following patterns ${ }^{7}$. The analysis of targets of the system (to formulate the aim as a choice of the modulating the tasks, to make the division of roles, to decompose the general purpose on the hierarchical subordinated aims);

- the reseachment of the system's structure and functions (the reveal of the functional characteristics of the system, the indentification of the best results in the accordance with the structure and functions);

- the improvement of the mechanisms of system formation (the movement form the statical to the dynamical research of system, the interaction of its elements and its development, the characterizing of its factors that lead to the systematical contradictions, the characteristics of the best means, its disposal or its minimization and eliminating of the necessary conditions).

For the elimination of the above mentioned theoretical and methodological concepts of the construction of the model of competences formation we based on the aim - the formation of the linguistics and methodological competences of the future foreign language school teachers and its social demand to train a competent school teacher.

The modern European school requires the competent teachers who are able to act mobile and effectively, who are able to solve the problems of different difficulties that appear during the educational process ${ }^{8}$. Thus, the linguistic and methodological competences are ones of the invariant components of the professional training of the foreign language school teacher and these competences are represented in our research as the individual innovative new formation. The basis of the linguistic and methodological training lies in the science of linguistics and didactics which is considered to be built on the general and special principles of foreign language teaching. This complete process depends on didactical aim and tasks of the learning material in the conditions of bilingual education.

We are interested in the opinion of the researcher I. Pentyliuk (2000) who considers the science linguistics and didactics as the "... notion that means to indicate the functional parts of the methodology science where the rules of mastering the language are investigated, the difficulties of the content of mastering the language and theirs reasons are studied, where the principles and methods of the learning process are indicated and the means of the formation of the communicative competence are investigated"9.

\footnotetext{
${ }^{7}$ Якиманська И.С.Личностно ориентированное обучение в современной школе. Москва : Издат. фирма «Сентябрь» 1996. 92 с.

${ }^{8}$ European Commission. (2007). Key competences for lifelong learning: European reference framework. Luxembourg : Office for Official Publications of the European Communities (in English).

${ }^{9}$ Пентилюк M.І. Культура мови і стилістика. Київ : Вежа, 1994. 239 с.
} 
The scientific researcher N. Ostapenko includes to the notion "linguistics and didactics competences" the knowledge, skills, appraisal attitude and the experience of the subject competence ${ }^{10}$.

Consequently, it is possible to make a conclusion that the sciences of linguistics and didactics are the foundation of the investigated psychological and didactical competences of the foreign language teacher.

Their professional component depends on their formation that stipulates the analysis of its content and the structure of the professional activity of the future school teachers. We are going to define their content:

The language competence foresees the formation of the knowledge of vocabulary units (this is meant to be a system of language). Another words there are the knowledge of syntactic, grammatical, phonetic, lexical, phraseological, orthographic (spelling) and semantic units of the language ${ }^{11}$.

The linguistic competence grounds on the skills to express the thoughts as in the oral speech as in the written one ${ }^{12}$.

The didactical competence means the presence of skills in the methodology of teaching the language using the mentioned skills in practice of foreign communication with the help of technologies that assist the development of didactical, management, analytical, communicative and perceptional skills of the pedagogue.

The psychological competence reveals the mastering the system of knowledge of people as the subject of educational process, students' age and individual peculiarities and social factors of their development; the mastering of the communication processes, the comprehension how these processes influence on achieving goals; the mastering of projecting, realization, appraisal and correction of the education process ${ }^{13}$.

Thus, we are certain that the professional component has a great impact on the training of the school teacher. The content of professional component divides into language, linguistic and didactical competences.

${ }^{10}$ National Council of Educational Research and Training (NCERT). (2005). National Curriculum Framework, India. Retrieved September, 15. URL: http://www.ncert.nic.in/ rightside/links/nc_framework.html (in English).

11 Мішеніна Т.М. Теорія і практика формування дидактичної компетентності майбутніх учителів філологічних спеціальностей : монографія. Київ : Педагогічна думка, 2013. 336 c.

${ }^{12}$ Волченко О.М. Формування комунікативної компетенції майбутніх учителів іноземних мов у вищих педагогічних навчальних закладах : дис. ... канд. пед. наук : 13.00.04. Київ, 2006. 261 с.

13 Ягупов В.В. Педагогіка : навчальний посібник для студ. пед. спец. вищ. навч. закл. Київ : Либідь, 2002. 559 с. 


\section{Components of linguistic and methodological competences}

We defined the components of structural and functional model of the process of linguistic and methodological competences formation of the future foreign language teachers. Among them are motivational component, cognitive component, management and practice components, appraisal and reflective ones. These all components are the components of our research process.

The motivational component includes the system of motives that express realized tend of the action. Among them, there is the intention to the education that is the complex of all mental activities due to which the behavior of people is indicated in general. This component leads a man to act and achieve the goals. There are two aspects of any activity: 1) the inner aspect - it stipulates the needs, interests, convictions and feelings; 2) the external one - it is connected with the intentions to the development and formation of the mentioned motives (the definition of $\mathrm{O}$. Yaroshenko $(2004)^{14}$.

The cognitive component is distinguished in all types of linguistic and methodological competences: special competence, didactical, methodological, scientific and researching ones. According to the theory of personality, every person creates its own system of the cognitive "individual constructions" that have different complex and content. Due to this system, a person can estimate the environments, people around and itself.

Due to the practical training, the students comprehend the grounds of methodological skills of the education, development, and the scientific teaching process, upbringing of pupils at school during the work in the class and out of it as well during the scientific and educational work. On the practical classes of the foreign language and methodology of teaching and the rest of the professional methodology courses (for example, the methodology of teaching the native language, the methodology of teaching mathematics, the methodology of teaching natural science etc.) the students are mastering the methodological recourse (it concerns their skills), that means how to manage the lessons of foreign language at school. This will lately combine their knowledge into one integrated methodological complex.

The students master the methodological skills during the practical classes of the methodology of teaching the foreign language as well as during the pedagogical practice at school. While being a teacher in the class students use the methods of modeling the lesson. The achieving experience indicates not only the level of their knowledge about the language but also the formed

14 Ярошенко О. Методична підготовка майбутніх учителів: реальний стан і шляхи. Вища освіта Украӥни. 2004. № 1. С. 69-73. 
ability to manage the lessons at school of the foreign language and to organize the methodological process as well.

The organization of methodological contain of the cognitive component is managed with the help of the dialogue forms of communication in the process of interaction that is implemented through the game-playing conception and the content of didactical game and it is realized through the mastering the disciplines of philological, didactical, methodological, pedagogical and psychological directions of the professional training.

The management and practice components. We connect the modeling of the pedagogical system with the phases of formation of the linguistic and methodological competences of foreign language school teachers. These phases will assist in the relations of the object of interaction with its executed actions.

The term process (from lat. - the passing ahead) is the determined, consistent, endless change of the development of something that is executed one by one.

The linguistic and didactical grounds of the theory of education are based on the ground of phased formation of linguistic and methodological competences of future foreign school teachers.

In our research, we distinguish three phases where the process of linguistic and methodological competences formation completes. There are: the preparatory phase, fundamental phase and final one. They are different by the targets, contents, methods and technology interactions, directions of the learmimg interaction (the foreign language and communicative ones). Every phase has its specifics and eliminates the condition of formed linguistics and methodological competences of the future school teachers from the minimal level up to the optimal one. We are going to characterize them from the position of structural and functional model.

A great number of the scientific researches accept the role of online didactical games in their pedagogical experience. They hold the opinion that didactical game is the method that may be effectively used with the aim from the one side to form the foreign language communication of the professionals and from another side to train the specialists for their future profession.

In the context of the foreign teaching process, the online didactical game has the following advantages:

a) It is the main mean to attract the participants of the game to the one common cognitive activity;

b) It forms the active position of every participant of the game in the common activity; 
c) It develops the interaction and role communication with the means of foreign language, and it creates not only the educational and developing environment but also the emotional and expressive ones;

d) It assists to the effective comprehension of lexical and grammatical materials of the language, which is being learned, and the language that is the foundation of the subject competences formation;

e) It develops the skills for modeling and integration of skills that foresee the use of the game method as the teaching one. It has the aim to obtain the professional skills and activity (as critical thinking, mobility and creativity) that are the special requirements to form practical skills in the work with the pupils at school.

Appraisal and reflective components include the professor's estimation of the students' pedagogical activity and students' self-estimations of the achieved goals, the conformity of tasks' requirements that were set, the projecting of new results, the controlling of the training results, the identification of the errors and their correction.

The process of learning is considered to be directed on the formation of the students' readiness for reflexion. This training is characterized by the social and psychological qualities of the future teacher and it foresees the comprehension of the process and the results of the activity, the obtaining of the skills to analyze and to identify the errors with the aim to increase the effectiveness to solve the educational tasks. In this context, the students' reflection is considered not only as the accumulation of the information about themselves but also students have a sense of the emotional experience and attitude to this reflection. Another words the reflection is based on the systematical self-analysis and there is the general condition of the movement from the education to the self-education. Self-appraisal has the complex character as far as it distributes on the different displays of the personality for example, the intellect, the appearance, the progress in communication and so on. Self-appraisal is the dynamic process and it can be changed during a life.

The self-appraisal plays the important role in the process of professional and pedagogical competences formation. If it has an adequate character, it provides the improvement of professional skills and knowledge. When the student appraises itself as an individual of the professional activity, he/she has an opportunity to take part to any professional activity. The ability of the individual and professional self-appraisal cannot be formed spontaneously. At first, the future school teachers esteem themselves as the pedagogues during the pedagogical practice when they have the first familiarity with the future profession. While analyzing their successes and fails, their appraisal of other people and comparing themselves with the real professionals' 
students develop their self-appraisal adequately and they develop the need to make the self-analysis and professional reflexion.

In our investigation, we organized the online didactical game on the teachers' training classes. Therefore, we were able to define the impact of the linguistic and methodological competences formation on the first and the last phases. The results were demonstrated on the practical classes of the following disciplines: Methodology of teaching the foreign language and Practice of the foreign language. All the courses were led according to the educational program English language (1-4 forms) and all the age peculiarities of primary school pupils were taken into account. All the students in the experiment were divided in two groups: testing and control ones. The changes in the control group were not so obvious before and after the experiment. At the same time the results in the testing group showed the best result after having included the online didactical games in their training process. Thus, the indexes of the control group changes from $33.3 \%$ to $40.6 \%$ in the students results on the high and satisfactory levels, when the indexes in the testing group rose from $31.9 \%$ to $56.9 \%$ on the same levels.

The figure 1 demonstrates the changes in the testing and control group.

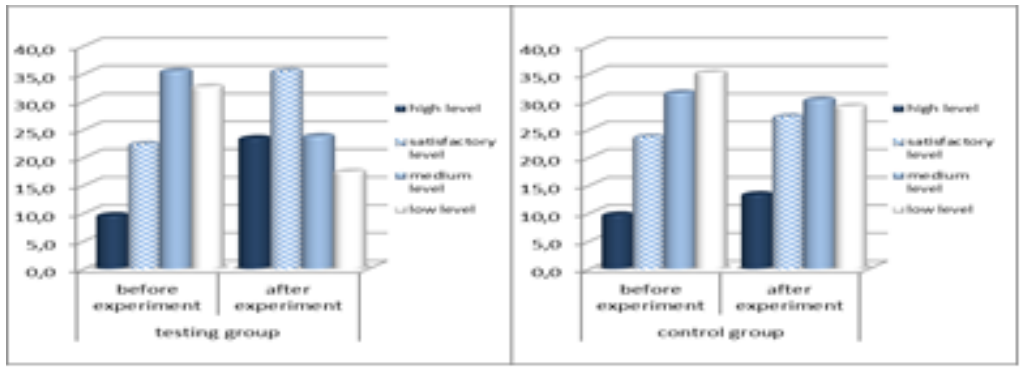

Figure 1. Dynamic of changes in the experimental research of using online didactical games in the future English teachers' training

On the graphic of the levels of linguistic and methodological competences formation of future English teachers in primary school through the online didactical games, we can notice the obvious dynamic of their increase $-14.5 \%$ in the control group and $53.8 \%$ in the experimental one.

\section{CONCLUSIONS}

In conclusion we can summarize that the linguistic and methodological competences which are discovered as the complex with all the components may be characterized as the integrative quality of student as a future foreign language school teacher. 
The competence approach input to the sphere of education brings the special status not only as the getting the knowledge, but as the using of the following knowledge and skills in the process of individual and professional selfdevelopment and self-appraisal. An experimental verification of pedagogical conditions and methods of the conception of the linguistic and methodological competence formation within the developed educational model effectiveness is performed. The professional online didactical games complex is developed on purpose to linguistic and methodological competence formation of the future foreign language teachers of elementary school.

The organization of linguistic and methodological competences formation of the future English teacher in primary school is managed with the help of the dialogue forms of communication in the process of interaction that is implemented through the game-playing conception and the content of didactical game. It should also be realized in the further teachers' training through the mastering the disciplines of philological, didactical, methodological, pedagogical and psychological directions of the professional training.

\section{SUMMARY}

The paper is dedicated to the theoretical and technological aspects of linguistic and methodical competences formation of the future foreign language teachers at school through the online didactical games. The nature of invariant term "linguistic and methodological competence" as the component of professional foreign language teachers' training of school was defined on the basis of theoretical and methodological analyses of two competences: "linguistic" and "methodological" ones. The content, structure and components of linguistic and methodological competences are determined; their formed criteria, indicators and standards are developed. An experimental verification of pedagogical conditions and methods of the conception of the linguistic and methodological competences formation within the developed educational model effectiveness is performed. The professional online didactical games complex is developed on purpose to linguistic and methodological competence formation of the future foreign language teachers of elementary school. The effectiveness of using online didactical games is proved on the increasing of future specialists training.

\section{REFERENCES}

1. Алексеева И.С. Профессиональное обучение переводчика : учебное пособие по устному и письменному переводу для переводчиков и преподавателей. Санкт-Петербург : Союз, 2001. 288 с. 
2. Волченко О.М. Формування комунікативної компетенції майбутніх учителів іноземних мов у вищих педагогічних навчальних закладах : дис. ... канд. пед. наук : 13.00.04. Київ, 2006. 261 с.

3. Гончаренко С. Український педагогічний словник. Київ : Либідь, 1997. $376 \mathrm{c}$.

4. Коменський Я.А. Велика дидактика. Москва : Начальна школа, 1983. $227 \mathrm{c}$.

5. Мішеніна Т.М. Теорія i практика формування дидактичної компетентності майбутніх учителів філологічних спеціальностей : монографія. Київ : Педагогічна думка. 2013. 336 с.

6. Остапенко Н.M. Теорія i практика формування лінгводидактичних компетентностей $\mathrm{y}$ студентів філологічних факультетів ВНЗ. Черкаси : Видавець Чабаненко Ю, 2GGS. 330 с.

7. Педагогічні технології в неперервній освіті : монографія / С.О. Сисоєва, А.М. Алексюк, П.М. Воловик та ін. ; за ред. С.О. Сисоєвої. Київ : Віпол, 2001. 502 с.

8. Пентилюк М.I. Культура мови і стилістика. Київ : Вежа, 1994. $239 \mathrm{c}$.

9. Рубинштейн С.Л. Проблемы способностей и вопросы психологической теории. Вопросы психологии. 1960. № 3.

10. Саюк В.І. Професійна підготовка вчителя до ігрових технологій навчання. Післядипломна освіта: перспективи розвитку : матеріали звітн. наук.-практ. конф., 28 листопада 2000 р. / Центр. ін-т післядипломної пед. освіти АПН України ; редкол. : В. Олійник та ін. Київ, 2001. Ч. 2. С. 123-128.

11. Семеног О.M. Професійна підготовка майбутніх учителів української мови і літератури : монографія. Суми : ВВП «Мрія-1» ТОВ, 2005. $404 \mathrm{c}$.

12. Сідун М.M. Формування професійної компетентності майбутнього вчителя іноземної мови початкової школи засобами навчальних ситуацій: дис. ... канд. пед. наук : 13.00 .04 «Теорія $\mathrm{i}$ методика професійної освіти» / Інститут педагогіки НАПН України. Київ, 2013. 248 с.

13. Ягупов В.В. Педагогіка : навчальний посібник для студ. пед. спец. вищ. навч. закл. Київ : Либідь, 2002. 559 с.

14. Якиманська И.С. Личностно ориентированное обучение в современной школе. Москва : Издат. фирма «Сентябрь», 1996. 92 с.

15. Ярошенко О. Методична підготовка майбутніх учителів: реальний стан і шляхи. Вища освіта України. 2004. № 1. С. 69-73.

16. American Library Association. (2000). The Information Literacy Competency Standards for Higher Education. Chicago, Illinois. Retrieved 
July 14, 2016. URL: http://www.ala.org/acrl/standards/ informationliteracycompetency (in English).

17. European Commission. (2007). Key competences for lifelong learning: European reference framework. Luxembourg: Office for Official Publications of the European Communities (in English).

18. European Commission. (2008, November 30 - December 2). Digital Literacy European Commission Working Paper and Recommendations from Digital Literacy High-Level Expert Group. Report presented at E-inclusion Ministerial Conference \& Expo. Vienna, Austria (in English).

19. National Council of Educational Research and Training (NCERT). (2005). National Curriculum Framework, India. Retrieved September, 15. URL: http://www.ncert.nic.in/rightside/links/nc_framework.html (in English).

\section{Information about the author: \\ Bozhok O. S., \\ $\mathrm{PhD}$ (Pedagogy),}

Associate Professor of the Department of the Methodology of Teaching Foreign Languages National Dragomanov Pedagogical University ORCID ID: orcid.org/0000-0002-0961-9008 